\title{
Peace Education in Canada: Teacher Perceptions of the Cultivating Peace Education Program
}

\author{
Afyare Abdi Elmi \\ Qatar University, Qatar \\ elmi@qu.edu.qa
}

\begin{abstract}
Many Muslims, Arabs, and other minority communities in Canada experienced the backlash of the September 11, 2001 events. Although these groups were discriminated against in a number of institutions, Muslim children in secondary schools in particular experienced different types of discrimination and violence. In order to help reduce incidents of discrimination in schools, with the help of academics at the Ontario Institute for Studies of Education (OISE), the Classroom Connections (non-for profit organization) developed a peace education program, the Cultivating Peace. Using qualitative methods, this paper examines the perceptions of teachers who used the Cultivating Peace program. Four themes emerged from the data collected for this research: flexibility, utility, relevance, and challenges. The findings reveal that educators believe the Cultivating Peace program promotes a culture of peace in Canada. Teachers find the Cultivating Peace flexible in that it fits well in the curriculum. In particular, teachers believe the program fits well in a social science and humanities curriculum. In addition, educators perceive the program is useful in teaching conflict resolution, communication, and problem-solving skills. They also find that the Cultivating Peace program is relevant to students' lives because it teaches values that promote a culture of peace. Teachers mentioned two major challenges: lack of time and distribution problems.
\end{abstract}

\section{Introduction}

Canada is a multicultural country, a microcosm of the world, where many people from different parts of the world live, work, and study together. For example, Toronto is one of the most multicultural cities in the world. According to Census Metropolitan Area (2002) data, about $75 \%$ of Torontonians of the ages 15 or older have direct ties to the immigration experience. In addition, $52 \%$ of Toronto residents are immigrants, while another $22 \%$ are second generation immigrants with at least one parent born outside Canada. The same census shows Vancouver and Montreal are also ethnically diverse cities. This diversity means that Canadians, especially new Canadians, have different and possibly conflicting ideas and conceptions about acceptable behaviours in society. In Canada, where peace and tranquility exist, many structural injustices are nonetheless rooted in the culture and the political systems of the society. Racism, sexism, and other types of discrimination are everyday realities for many Canadians. Muslims and Arabs, because of the events of September 11, 2001, face serious challenges in integrating into mainstream society.

The purpose of this research is to examine teachers' perceptions of Cultivating Peace (a peace education program for Canadian schools). The Cultivating Peace program was designed to promote a culture of peace in Canada by teaching students the knowledge, skills, and attitudes that prepare them to deal with conflicts non-violently. Using qualitative research methods, this

Journal of Contemporary Issues in Education, 2009, 4(2), pp.41-54

ISSN 1718-4770 (C) 2009 University of Alberta

http://ojs.educ.ualberta.ca/index.php/jcie/ 
paper explores how educators perceive this program to accomplish its goals of contributing to the promotion of a culture of peace in Canada. The paper consists of four sections. I will describe the content of the Cultivating Peace program by discussing the components of the video and the booklet in the first section. Secondly, I will briefly explain my methodological approaches followed by the analysis of the findings. Finally, the paper will conclude with the implications and recommendations of this research project.

\section{Cultivating Peace: Background and Description of the Content}

Cultivating Peace is a peace education program developed in Toronto with the help of academics from the Ontario Institute of Educational Studies at the University of Toronto, the International Institute of Global Education, and Classroom Connections - a not-for-profit organization that focuses on educational development in Canada. Citizenship and Immigration Canada and Canadian Heritage funded the program. Classroom Connections outlines the need for the Cultivating Peace program and the rationale behind its creation in the introduction of the package. According to Classroom Connections, the September $11^{\text {th }}$ terrorist attacks on New York and Washington and the violent conflicts that followed underscored the importance of how people view global citizenship, conflict resolution, and positive peace. Classroom Connections also believes that education has the strongest force in changing society.

Many Muslims, Arabs, and other minority communities in Canada experienced the backlash of the September 11 events. Although these groups were discriminated against in a number of institutions, Muslim children in secondary schools in particular experienced different types of discrimination and violence. In order to help reduce incidents of discrimination in schools, Classroom Connections came up with the idea of developing a peace education program aimed at students. The organization eventually produced the Cultivating Peace program.

The Cultivating Peace program consists of a videotape and a 60-page booklet. There are four different segments in the video. The first cartoon, "Neighbours", is about eight minutes long. It shows a conflict between two neighbours over a flower that is located on the border between their homes. This segment is designed to teach students about conflicts over resources. The second segment, "Balablok", illustrates conflict over difference through the use of cubes and spheres as characters. As the cubes are walking they see spheres. They cannot tolerate each other because they are different. This segment teaches students that conflicts can occur when differences exist.

The third segment, "When the Dust Settles", shows the escalation of violence between two gophers over a misunderstanding. It demonstrates to students how conflict can easily escalate over something trivial. The final segment, "Taking Action", shows real-life conflict between the Canadian government and the people. Thousands of people demonstrated against the policies of the 34 leaders of American states in the 2001 Quebec Summit of the Americas. This huge protest employed different strategies. Some protestors were arrested because they were out of control. Others, although not arrested, used unconventional tactics to protest when approached by police (such as taking off their clothes). Taking Action is designed to teach students that there are a number of ways to deal with conflict.

In addition to the videotape, the Cultivating Peace education program contains a 60-page booklet. This booklet consists of an introduction and seven lessons. The introduction outlines reasons that led Classroom Connections to create the program. It also discusses how the Cultivating Peace program fits into different jurisdictions in Canada. The authors have explored 
social studies curricula within different Canadian jurisdictions and identified how the program could be easily adapted to fit the curriculum of the different provinces. In addition, the authors that designed Cultivating Peace advise educators who would use this program on how they could teach it. They recommend a pedagogy that is consistent with peace values being taught to students. They have allocated a section on the appropriate pedagogy. They suggest that educators use the "learning through" approach where the process used is as important as the content taught (Classroom Connections, 2002, p. 8). This is a shift from the content-focused programs that teach positive values without taking into account the process. If, for instance, a teacher wants to teach peace values but uses violent or authoritative ways, the process used is different from the intention and the content of the program. Keeping this in mind, Classroom Connections encourages teachers to use respectful means when teaching culture of peace values.

Seven lessons with similar structure follow the introduction. Each lesson includes objectives/expectations, key concepts and issues, materials needed, lesson overview/potential, procedures that educators can use to deliver the lesson, possible variations, discussion questions, and assessment. The first chapter of the booklet, "Peace-More Than Just A Symbol," provides student activities and different definitions of peace. Teachers are given clear instruction on how to deliver the program.

In the second lesson, "Causes of Conflict, Violence and War," by using the first three parts of the videotape and two articles ("Terrorism as Cannibalism" and "Manhood and Violence"), students delve into the causes of conflict, violence, and war. The intended messages of this lesson include how conflicts occur over competition for resources, difference, and misunderstanding. It was suggested that students also discuss the two articles as well as an overhead entitled Peace, Violence and Conflict. This lesson introduces students to other sources of conflict such as class conflict, racism, and fundamentalism.

Lesson three, Security - More Than Just Defence, and Lesson four, Deeper Security-A Case Study, present concepts of security. Students are expected to examine different definitions of security and how measures taken could affect them. Students also study the Universal Declaration of Human Rights. Through case studies of two students, they also explore the security of minority students.

In lesson five, "Toward a Culture of Peace", through the use of political cartoons, students are expected to examine global justice, positive peace, and human rights. They examine the implication of the concept of a culture of peace. Moreover, lesson six, "Taking Action", presents different appropriate strategies used in different social and political actions. Using the video segment, which focused on the 2001 Quebec Summit, students are expected to discuss the strategies that protesters used.

Finally, in lesson seven, while reflecting on Arun Gandhi's article, "Terrorism and Nonviolence", students discuss their own contributions to creating a culture of peace. This lesson also introduces students to several important people such as Mahatma Gandhi, Martin Luther King Jr., Nelson Mandela, Abdul Ghaffer Khan, Ursula Franklin, and Jeanette Rankin - all of whom worked for peace.

\section{Research methods}

This study employs qualitative research methods. Data was mainly collected through semi-structured interviews. I have chosen qualitative methods for this research for two reasons. First, the goal of this study is to explore how six educators who used the Cultivating Peace 
program perceive it. Since major goals of qualitative research include description, exploration and understanding, such a method becomes the appropriate instrument for the task. Second, I have chosen qualitative methods because it appeals to me. I have used this method because it deals with real people's stories and experiences. That is what makes this method more attractive than quantitative methods, which seek to explain and predict (Merriam, 1998; Rothe, 1993).

\section{Findings and Analysis}

I interviewed six educators who teach the Cultivating Peace program to students. All interviews were tape-recorded and transcribed. The participants used the resource with high school students from Grades 9 to 12. Subjects reported the Cultivating Peace program was well suited to all social science and humanities courses available at the high school level. All six participants teach in urban high schools (two in Toronto, two in London, Ontario, one in Ottawa, and one in Fort McMurray). Four of the participants were female and two were male. In this section, I will present the findings of those interviews. There are four distinctive categories that the data can be grouped into: flexibility, utility, relevance, and challenges.

\section{Flexibility}

The six educators I interviewed reported using the Cultivating Peace program for different courses. For instance, some teachers used the resource for social science courses, finding it particularly suitable for world issues, sociology, politics, civics, and law courses. Other teachers also saw a fit for humanities courses. In particular, two teachers used the program for a grade 10 mandatory history course. One teacher reported that she used the Cultivating Peace program for a religion course, while another used it for an environmental science course at the grade 12 level. All six educators believed that the design of the resource made it suitable for most of the social science and humanities courses available at the secondary level.

The educators I interviewed also reported that they did not have to figure out how the program linked to curriculum. For instance, when asked why she liked the program, Maria replied:

You do not need to ask yourself, where does this program fit in the curriculum expectations? That work is done for you. And I think that is one thing that would draw a teacher to a program. It could also be that this resource is free of charge. That is big factor because educators are spending their own money to find appropriate material. (Maria, personal communication, April, 2004)

As Maria pointed out, the introduction of the booklet suggests which course and where the resource fits the curriculum.

The Cultivating Peace program, according to the educators I interviewed, is suitable for different grades. Teachers reported they had used the program with Grades 9, 10, 11, and 12 students. Responding to a question on whether the Cultivating Peace program was ageappropriate for secondary school students, Vicky said:

The program is absolutely age-appropriate. I think, that is, maybe many of these students deal with these issues in their own lives. I think it was appropriate. For my grade 10 and grade 11 students, I found the level was sophisticated enough to challenge students, but at 
the same time gave them the ability to read and to understand. (Vicky, personal communication, May, 2004)

Besides the curriculum suitability and age-appropriateness, the six educators reported that the Cultivating Peace program was produced at an appropriate time as it was made available in schools a year after the September 11 attacks. Michelle stated:

A year after 9/11 this material was available in the classrooms. It was fantastic because teachers were trying to find a way to help students deal with the issues of 9/11. And in Canadian and World Studies, this was the place. So it was very timely. (Michelle, personal communication, April, 2004)

Two other educators agreed with Michelle that the program was produced and distributed to the schools at the right time.

Responding to pedagogical questions, educators adopted non-traditional strategies when delivering the program. All of the teachers I interviewed said they did not lecture students when they taught the resource. They all used cooperative pedagogies where students worked in groups and attempted to address issues by debating. Since the resource was explicit about not using pedagogies that reinforce differential power relations, teachers reported that they followed the suggestions of the program designers. Becky, for instance, noted:

In one of the classes I remember, I did not discuss or lecture anything. I simply put in the video. The video focused their attention and then when the discussion started the students already understood the content. So this was a good attention grabber and gave the students a better perspective. (Becky, personal communication, October, 2004)

The extent to which the program was used differed among the six educators. Some reported they used only one-third of the program, while two teachers reported they used half, and one educator used three-quarters of the Cultivating Peace program. All of the six educators complained that they did not have enough time to teach the full program. Different teachers used the Cultivating Peace program differently. Three of them said they only used the resource once, two used it twice, and one reported using the program more than four times.

This suggests that the program is underutilized. The reason might be that most teachers in Canada are not still aware of the existence of the program since it has only been out for few years. However, the reason can also be in the way the program is distributed to schools. Some teachers said they found the program through the Internet or through friends. I believe the more teachers that receive the program, the more it will be used.

\section{Utility}

The teachers reported that the Cultivating Peace program was useful in promoting a culture of peace because it taught students problem solving, conflict resolution, and listening skills. They observed that students' reactions to the program were positive. They cited a number of examples. For instance, Nancy, commenting after students watched the protest against the Quebec Summit, said, "it was really interesting for them to see a different perspective, a political situation that people coming together around economics issue, and certainly people from alternative lifestyles protesting. Seeing and listening to what they had to say was interesting" 
(Nancy, personal communication, April, 2004). Nancy also said the students raised questions when they watched the tape:

Is this acceptable? How far do you take a protest? To respond to a policy you disagree with, should you be able to write a letter, or post a sign or should you be able to put yourself a risk or others' lives at risk? If you put your life in danger can you put somebody else's life in danger too? (Nancy, personal communication, April, 2004)

In fact, the quality of questions that Nancy reports illustrates how the Cultivating Peace program teaches students valuable knowledge and critical thinking skills. Students discover that they can challenge government policy non-violently. They also understand the tactics that civil society groups employ to oppose government decision. Moreover, Tom agreed with Nancy. In answering if the program was useful, he said:

The Cultivating Peace material makes students think about the causes of war, the causes of conflict, and ways they can be avoided. It teaches students to be aware of feelings toward those who are different. Students become aware their actions can have consequences on others. They learn about peace heroes, and how they themselves can be an agent to bring about change in the world. (Tom, personal communication, April, 2005)

The educators who used Cultivating Peace believed the program was useful in teaching a number of values that are necessary in promoting a culture of peace. Vicky summed up the values she thought the program taught: "I believe the program teaches peace, collaboration, reflection, empathy, responsibility, thoughtfulness, and questioning" (Vicky, personal communication, April, 2004). The authors of the Cultivating Peace resource designed the program to teach empathy, cooperation, fairness, respect and peacefulness (Classroom Connections, 2002, p. 8).

\section{Relevance}

The educators found the Cultivating Peace program was relevant to students' lives. They also reported that Cultivating Peace taught conflict resolution and listening skills while using graphic material. Maria, explaining how the program was pertinent to students' lives, said:

If it doesn't relate to their lives it doesn't mean any thing for them. If you talk about stuff that happened (in) WWI that is too far away for them. The further away you get, it is somebody else's problem. What is important to them is what they can apply in their lives. And that is what the program gave them. (Maria, personal communication, April, 2004)

Maria and Michelle told two stories regarding how the program was relevant for their students. Maria said:

In grade 10 history, we used from the video two short cartoon clips. The one about escalation of violence pops to mind. And there is no language, there is just music. I think it can be used in any classroom around the world, and I think anybody can understand it. What it explains or what you see is somebody does something to someone else accidentally. And then that person having a bad day or whatever, instead of saying "Oh 
you bumped into me and sorry about that," turns around and starts throwing something back. And then the conflict escalates and then two gophers end up digging holes almost killing each other. But in the end there is a moment where they stop and they look at each other and there is recognition that they are both destroying their own homes by trying to destroy the other. That is a basic knowledge because it portrays universal understanding. And I think that is key. We used it for the Grade 10 history course to help students understand the development of war and its escalation. And that can be applied and discussed in the historical context of WWI and WWII and the current Iraq war. (Maria, personal communication, April, 2004)

Michelle, discussing the relevance of the Cultivating Peace program to students' lives, provided the following example:

I think that the one thing that came to mind is the video on circles and squares. They are saying hello and then the one looks different. Then they start fighting. They fight so much that the ones they are fighting with take the same shape. Then they do not know what they are fighting about. I think because it was done about shapes the students could watch and laugh, but at the same time relate it to conflicts happening based on difference in people. And then the students gain sense of "Ha! We do the same thing. Why do we do that?" And they came to the conclusion that we are all the same inside. (Michelle, personal communication, April, 2004)

Both stories illustrate that the program was relevant to students because it used concepts and vocabulary students could understand and relate to their lives. These stories also show that some of the values the program embodies have an impact on the students.

Vicky, reported that the Cultivating Peace program was relevant because it

provided growing awareness of self and how each individual of society could be an agent of either peace or violence, because students consider all causes and sources of peace from an individual to group basis and from a local to international scale. (Vicky, personal communication, April, 2005).

In summary, the educators I interviewed believed the Cultivating Peace program teaches relevant values and skills to students.

\section{Challenges}

Although teachers valued this program, they did not use all of the material. Some used half of the program while others taught only a third of it. The reason for this was they had so many other things to cover. In addition, teachers argued students were exposed to some of the concepts already through other courses. Educators found time was the most important resource they lacked. Maria, responding to a question about challenges she faced, said:

This is a good program with Canadian content that is free. Many good conflict resolution and peace education programs are not necessarily Canadian-based. But, because of time, I could not teach all of the resource while also covering other content of the course. (Maria, personal communication, April, 2005) 
This obviously shows that the Cultivating Peace program, while useful, is subordinate to other contents that might be required in the curriculum. Maria and other teachers repeatedly said they were unable to use all the resources due to time constraints. Teachers are expected to cover what is in the curriculum before they look outside. Perhaps, Classroom Connections and other peace activists can lobby for making peace education a mandatory course.

The scholars who designed the Cultivating Peace program intended to produce a peace education program that taught u seful knowledge, skills, and values to promote a culture of peace. However, teachers, although they thought it contributed to a culture of peace, did not articulate how it promoted a culture of peace. Teachers simply saw the utility and relevance of this program since it taught sources of violence, conflict resolution skills, and communication skills. The reason is that teachers do not properly understand what constitutes a culture of peace. When asking questions, some directly asked me what I meant by a culture of peace. When I described it for them they could see the link. One way of addressing this is by providing a separate information package about the history and components of the United Nations Educational, Scientific and Cultural Organization's (UNESCO) culture of peace.

The teachers also reported that although administrators viewed the program favorably and encouraged its use, the way it was distributed made it inaccessible for many teachers. Classroom Connections did not send the material directly to schools, but rather sent it to district boards, which in turn, distributed it to their schools. Therefore, the material came to principals and vice principals and then they shared it with social science and humanities teachers. One of the teachers interviewed found the program through an Internet search while another one came to know about the program through a colleague. One reason might be that Cultivating Peace is still new. Another might be that there is distribution problem. None of the teachers suggested a better distribution system.

In sum, teachers found Cultivating Peace to be a useful, flexible, and relevant program. According to the educators, the program was useful because it taught problem solving, conflict resolution, and communication skills. They also felt it encouraged students to see other perspectives. In addition, the peace education program was teacher friendly. Those who designed the program researched all Canadian jurisdictions and identified how and where this program connects to the curriculum (Classroom Connection, 2002). Teachers that I interviewed reported the program fit the curriculum easily. In addition, teachers reported Cultivating Peace was age appropriate, having been designed for high school students. Teachers believe students could handle the concepts and ideas that the program taught. In fact, they pointed out that some of the video clips for the program did not require language. Classrooms Connections, the organization that produced this program, reported that they wanted to create a resource for each grade beginning with Kindergarten. However, they could not get funding for other classes.

Teachers felt that Cultivating Peace was a useful and appropriate peace education program for Canadian students. They believe the program balanced teachers' and students' needs properly. They also believe the program contributed to a culture of peace. They did not link how each segment of the program addressed the culture of peace components. They cited examples from the program that had great impact on students they observed. 


\section{Content Analysis}

Peace education is important in creating and promoting a culture of peace (Wessels, 1994). According to Wessels, families, communities, ethnic groups, and nations must be socialized in ways that promote non-violent conflict resolution, sustainability, and social justice in all possible forums through formal, informal, and non-formal education. However, peace education programs differ in the assumptions they are based on, the challenges they face, and the goals they are designed to attain (Solomon, 2002). Solomon classifies peace education into three categories: peace education in regions of intractable conflicts (Rwanda and Israel-Palestine), peace education in the regions of interethnic tension (Belgium and the United States), and peace education in regions of experienced tranquility (Canada). He argues those designing peace education programs must have conceptual clarity of the type of the conflict being addressed and appropriate peace education programs for the context.

Fountain (1999), defines peace education as the

process of promoting knowledge, skills, attitudes and values needed to bring about behaviour change that will enable children, youth and adults to prevent conflict and violence, both overt and structural; to resolve conflict peacefully; and to create the conditions conducive to peace, whether at an intra-personal, interpersonal, inter-group, national or international level. (p. 1)

I find Fountain's definition comprehensive in that it addresses what is to be taught, how, to whom, and the standards that could be used to measure success. In addition, Fisk (2000) discusses different ways of achieving peace through education, examining formal and nonformal peace education programs. He especially emphasizes the significance of non-formal peace education. As an example, he presents the impact that Rosa Parks' story had on the civil rights movement and how non-formal human rights education influenced her decision to resist the unjust laws. Regarding formal peace education, Fisk examines three different approaches: education about peace, educating for peace, and peace through education.

With respect to the appropriate pedagogy for peace educators and conflict resolution workers, John Paul Lederach (1991) compares two types of pedagogical approaches: The prescriptive model and the elicitive model. The prescriptive model is based on the assumption that the trainer is the expert and the trainee is student. In other words, the relationship between the trainer and the trainee is based on the conception that the participant is expected to take knowledge from the trainer. The trainee is passively involved in the training process, whereas the trainer is expected to effectively pass knowledge to the trainee. Lederach says this pedagogy is more effective when the trainer and the trainee come from the same culture. Moreover, as Joshee (2004) argues, the oftenused approach of liberatory education is not helpful when teaching diversity, social justice, or peace. This method, according to her, creates antagonism and guilt among members of dominant groups and focuses on specific types of violence. She suggests the use of Gandhi's Ahimsa principle as a more appropriate and holistic pedagogy when teaching peace. For Joshee, the elements of a pedagogy of Ahimsa are: re-evaluation of all types of power relations, focus on dialogue rather than debate, and imagination and creativity. Using the above scholars' frameworks of peace education, Cultivating Peace was designed to teach secondary school students knowledge, skills, values, and attitudes needed in 
creating a culture of peace. The program is open about the values it attempts to teach to students. It is noted in the resource that the program teaches cooperation, empathy, fairness, respect, peacefulness, tolerance, non-violence, diversity and social justice. In terms of knowledge, Cultivating Peace teaches universal human rights and different conceptions of peace and security. It also teaches conflict resolution skills.

The authors of Cultivating Peace encourage educators to use a process-based system that reduces the power difference between students and teachers. According to the resource, "what the activities and materials in this resource seek to do is to add the learning in (or through) approach, whereby the actual process of learning is as significant as the intended content of learning" (Classroom Connections, 2002, p. 8). Fisk (2000) argues that the "learning through" approach is superior to the "learning about" and "learning for" approaches. Cultivating Peace is based on Fisk's model in all of its aspects. This pedagogy is also consistent with Lederach's (1991) elicitive model. Lederach believes peace education can be more effective when students are empowered.

The Cultivating Peace program partially responds to Galtung's (2004) conception of violence and peace. Galtung understands violence as direct violence + structural violence + cultural violence $(2004$, I 2). He also considers peace to be the absence of direct violence + structural violence + cultural violence. Mainly, the program Cultivating Peace attempts to deal with direct violence. It teaches conflict resolution and non-violence. For example, the four segments of the videotape teach students different sources of conflict such as conflict over resources and conflict over difference. Regarding the structural violence, the program teaches the importance of respect among students. However, the program does not teach about cultural violence, perhaps because the students are not at the age where they would understand cultural violence.

The Cultivating Peace program also partially conforms to Wessels' (1994) principles of peace education programs that contribute to a culture of peace. Wessels argues that effective peace education programs have to be integrated to all social levels such as family, the school, and community. The Cultivating Peace program targets high school students in school contexts. I believe this program can also be taught to adults and small children in different contexts, in non-formal and informal ways. For example, the video segments that teach sources of conflict and peace can be aired on educational channels on television. The resource can also be distributed to different community centres in the country.

In addition, Wessels (1994) argues that peace education programs that contribute to a culture of peace emphasize cooperation rather than conflict and teach values of empathy and multicultural understanding. The Cultivating Peace program emphasizes cooperation. All the activities in the lessons suggest that students should work together. The resource explicitly encourages cooperative pedagogies (Classroom Connections, 2002). Moreover, educators are expected to be sensitive when teaching the material (Classroom Connections, 2002). Regarding values, the Cultivating Peace program was designed to teach empathy (Classroom Connection, 2002).

Finally, Cultivating Peace is consistent with the UNESCO's understanding of a culture of peace. UNESCO (UNESCO, 1998) identified six components: respect for human rights and freedoms; commitment to non-violence; adherence to principles of justice; democracy and tolerance; commitment to development and environment; and equal rights for women and men. The authors of Cultivating Peace acknowledge these components in the second page of the resource (Classroom Connections, 2002). Close observation of the different units of the resource 
also reveals that Cultivating Peace directly addresses the first four components. For instance, the resource teaches human rights and sources of conflict. However, while it partially deals with gender equality, the program does not consider commitment to the environment and development. Regarding the equality between women and men, the resource discusses very few women peace heroes. Pictures of peace heroes in the back of the book are mostly male such Mahatma Gandhi, Nelson Mandela, and Martin Luther King. The resource provides a list of 18 peacemakers, and women represent about $40 \%$.

\section{Conclusion and Recommendations}

Peace education programs are expected to contribute to a culture of peace when they result in behavioural change (Fountain, 1999; Galtung, 1996). Knowledge, skills, and values are taught to students so when conflicts occur they are equipped to deal with them non-violently. Nevo and Brem (2002) argue that the goal of a peace education program is either to develop certain skills or to reduce specific sets of behaviours. The skill sets that peace education programs teach include conflict resolution, empathy, tolerance, and communication. Nevo and Brem argue some peace education programs are designed to lessen or decrease certain types of behaviour. These behaviours include aggression, violence, prejudice, stereotyping, and ethnocentrism. Galtung (1995) agrees with Nevo and Brem. He argues that conflicts occur because of attitudes/assumptions, behaviour, and contradiction (ABC). Galtung claims a conflict can start at any corner of the $\mathrm{ABC}$ triangle, but he believes that the behaviour is the only observable part as attitudes and contradictions are difficult to spot or observe.

This study was not designed to measure students' behavioural changes after the program. It examined the teachers' perceptions of the program. The findings of the study suggest that the educators who used Cultivating Peace in their classes perceive that the program contributes to promoting a culture of peace in Canada. They think the program is flexible, useful, and relevant. Teachers believe the Cultivating Peace program is a good fit with the curriculum, and it is ageappropriate. In addition, the teachers think that Cultivating Peace is useful in that it teaches conflict resolution, communication, and listening skills. Educators also reported the program teaches relevant values that are consistent to the students' lives.

According to the Hague Agenda for Peace and Justice for the $21^{\text {st }}$ Century, humanity can achieve a culture of peace when "citizens of the world understand global problems, have the skills to resolve conflicts and struggles for justice non-violently, live by international standards of human rights and equity, appreciate cultural diversity, and respect the earth and each other" (Classroom Connections, 2002, p. 2). UNESCO has also identified six components of the culture of peace: respect for human rights; rejection of violence in all its forms; commitment to the developmental and environmental needs of present and future generations; promotion of equal rights and opportunities of women and men; recognition of freedom of expression; and devotion to principles of justice and democracy (UNESCO, 1998). Although all of the teachers I interviewed perceived Cultivating Peace as contributing to the culture of peace, they did not articulate how it did so. For them, since the Cultivating Peace program taught conflict resolution, communication, and listening skills, it contributed to the promotion of the culture of peace in Canada. A separate program including a brief history of UNESCO's culture of peace and its components would help teachers understand the goals of Cultivating Peace.

In sum, the teachers' perception was that the Cultivating Peace program is an appropriate peace education program for Canadian students. They believe this program balances teachers' 
and students' needs properly. To address problems of violence, teachers need a program that is consistent with the curriculum, which teaches conflict resolution skills, tolerance and peace values. Students, in order to lead better lives, need these skills for their own development. Teachers also believe this program contributes to the culture of peace. They did not explain how each segment of the program addressed the culture of peace components. They did cite examples from the program that had a great impact on the students they observed. One of the teachers remarked that she was interested in teaching students valuable lessons about non-violence and peace and Cultivating Peace provided her that opportunity.

Interviews consistently revealed two areas where improvement was needed. First, a good part of the Cultivating Peace program is not used. Most of the time, teachers used the videotape rather than the reading kit. I think the reason for using the videotape is that it is visual. The first three programs are also short and easily understandable. Teachers also justified their selective use of some parts of the program due to lack of time. Interviews also show the videotape was used more than the booklet. Although the sample of educators I talked to does not warrant generalization, I think peace educators should keep this in mind when designing future peace education programs. This does not mean text- and audio-based programs are not useful.

Since my study is not quantitative research, this finding is not conclusive. It states that the teachers I spoke with used the videotape more than they used the booklet. Further research is needed. To respond to the limited usage of Cultivating Peace, I think efforts should be made to make this an independent course that is available at the schools. To do so, different levels of authorities that manage education institutions have to be convinced. Classroom Connections can lead this effort, but educators (both those who used the program with students and those who designed it) have to also help.

The second area is the distribution of the program to schools. Classroom Connections sends their resources to school boards. Boards then share the program with their schools and the administration of the schools gives the resources to the teachers. This is a long process. If possible, I think it would be more efficient if a database of schools could be created nationally. Teacher colleges, unions, and local media could also be used for the promotion of the peace education program. Teacher colleges are very important for the distribution of the peace education programs. I think, besides distributing, teacher colleges must teach peace education courses and should introduce useful resources such as Cultivating Peace. Some teachers in the study informed me that they found the program through friends or Internet searches. For more teachers to know about the existence of the program, I think those involved in the program should use every media opportunity they can find. Classroom Connections should also consider convincing television stations such as TV Ontario to air the video program and talk to one of the designers or program administrators. Besides the promotion of the program, the act itself educates the general public non-formally.

In conclusion, although educators who used Cultivating Peace liked the program, further research is needed. My research was limited in a number of ways. For example, I did not talk to the students, administration, or parents. I also did not examine the effects Cultivating Peace had on students. Studying the impact that Cultivating Peace has had on students as well as the specific values that are learned would also help future designers of peace education programs.

The Cultivating Peace resource has all the characteristics of a peace education program for what Solomon (2002) calls "countries of tranquility." Canadians of different cultures, races, and backgrounds live and work together. Although discrimination exists within Canadian institutions, the country generally functions well. Cultivating Peace is a short but comprehensive 
program that teaches sources of conflict, violence, and peace. The resource employs cooperative pedagogies that minimize different power relations. Cultivating Peace teaches high school students values, attitudes, skills, and knowledge based on commitment to non-violence and human rights. The program emphasizes empathy, cooperation, and tolerance.

I think the videotape segments, particularly the first three (Neighbours, Balablok, and When the Dust Settles) can be used universally. These three segments teach three sources of conflict: conflict over resources, conflict over difference, and conflict over misunderstanding. Some parts of the booklet can also be used in different contexts. For example, knowledge of universal human rights principles is useful. The program is flexible in a number of ways. It can fit, as the educators I interviewed noted, in the formal high school context. I believe limiting the use of the program to the formal contexts will unnecessarily restrict benefits of the resource to one segment of society - the high school students. I believe Classroom Connections and educators who are familiar with Cultivating Peace should present the program non-formally and informally. In other words, instead of targeting just the high school students, Cultivating Peace should target all Canadians in different settings. As stated by Wessels (1994), effective peace education programs that contribute to a culture of peace have to be integrated into all social levels such as family, the school, and community. 


\section{References}

Census Metropolitan Area. (2002). Statistics Canada. Retrieved March, 2005, from http://www40.statcan.ca/101/cst01/demo05a.htm

Classroom Connections. (2002). Cultivating peace. Retrieved 01/05/10 from http://www.cultivatingpeace.ca/main.html

Fisk, L. (2000). Shaping visionaries: nurturing peace through education. In L. Fisk \& J. Schelleberg (Eds.), Patterns of Conflict, Path to Peace. Peterborough, ON: Broadview Press.

Fountain, S. (1999). Peace education in UNICEF. Working paper by Education Section: Program Division (see www.unicef.org).

Galtung, J. (1990). Cultural violence. Journal of Peace Research, 27(3), pp. 291-305.

Galtung, J. (1995). Cultural peace: Some characteristics. In UNESCO, From a Culture of Violence to a Culture of Peace. (pp. 75-93). Paris: France UNESCO Publishing

Galtung, J. (1996). Peace by peaceful means: Peace and conflict, development and civilization. London: Sage Publications.

Galtung, J. (2004). Peace education: Typology. Retrieved June, 2005, from http://www.dadalos.org/frieden_int/grundkurs_2/typologie.htm

Joshee, R. "Is Peace the Answer?" American Educational Research Association [Conference]. San Diego, California. April, 2004.

Lederach, J. P. (1991). Beyond prescription: New lenses for conflict resolution training across cultures. Waterloo: Inter-Racial and Cross-Cultural Conflict Resolution project.

Lederach, J. P. (1997). Building peace: Sustainable reconciliation in divided societies. Washington, DC: United States Institute of Peace Press.

Merriam, S. (1998). Qualitative research and case study in education. San Francisco: JosseyBass Publishers Press.

Nevo, B. \& Brem, I. (2002). Peace education programs and the evaluation of their effectiveness. In G. Solomon \& B. Nevo (Eds.), Peace Education: The Concept, Principles, and Practices Around the World. (pp. 271-283). Mahwa, New Jersey: Lawrence Erlbaum Associates.

Solomon, G. (2002). The nature of peace education: Not all programs are created equal. In G. Solomon \& B. Nevo (Eds.), Peace Education: The Concept, Principles, and Practice Around the World.. Mahwah, New Jersey: Lawrence E. Associates.

United Nations Education, Scientific and Cultural Organization (UNESCO). (1998). A Consolidated report submitted to the Secretary General of the United Nations to the fiftythird session of the General Assembly, Towards Culture of Peace. Retrieved 09/01/10 from http://www.un-documents.net/a52r13.htm

United Nations General Assembly. (1999). Resolution adopted by the GA: Declaration and programme of action on a culture of peace. 53/243. New York: United Nations General Assembly.

Wessels, M. (1994). The role of peace education in a culture of peace: A Social Psychological Analysis.Eric \# 384 549. ISSN 1101 6418. Retrieved 09/01/10 at http://www.eric.ed.gov/ERICWebPortal/custom/portlets/recordDetails/detailmini.jsp?_nf $\mathrm{pb}=$ true\&_\&ERICExtSearch_SearchValue_0=ED384549\&ERICExtSearch_SearchType $\_0=$ no\&accno $=E D 384549$. 